\title{
Bioactivity of two Turkish endemic Centaurea species, and their major constituents
}

\author{
Mohammad Shoeb ${ }^{1}$, Stephen M. MacManus ${ }^{2}$, Marcel Jaspars ${ }^{3}$, Paul Kong-Thoo-Lin ${ }^{4}$, \\ Lutfun Nahar ${ }^{4}$, Sezgin Celik ${ }^{5}$, Satyajit D. Sarker ${ }^{6 *}$ \\ ${ }^{1}$ Department of Chemistry, University of Dhaka, Dhaka-1000, Bangladesh,

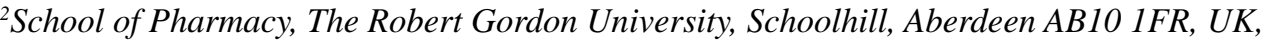 \\ ${ }^{3}$ Marine Natural Products Laboratory, Department of Chemistry, University of Aberdeen, \\ Aberdeen AB24 3UE, UK, \\ ${ }^{4}$ School of Life Sciences, The Robert Gordon University, St Andrew Street, \\ Aberdeen AB25 1HG, UK, \\ ${ }^{5}$ Department of Biology, Faculty of Science and Literature, Canakkale Onsekiz Mart University, \\ 17020 Canakkale, Turkey, \\ ${ }^{6}$ School of Biomedical Sciences, University of Ulster at Coleraine, Cromore Road, \\ Coleraine BT52 1SA, Co. Londonderry, Northern Ireland, UK
}

\begin{abstract}
RESUMO: "Bioatividade e os principais constituintes químicos de duas espécies de Centaurea, endêmicas da Turquia”. A atividade antioxidante, a toxicidade geral e a citotoxidade dos extratos metanólicos de Centaurea urvillei subs. armata e C. mucronifera foram analisados, respectivamente, pelo ensaio DPPH e pelos ensaios de letalidade de Artemia salina e de citotoxidade MTT. A análise dos extratos metanólicos em CLAE de fase reversa apresentou duas lignanas biotivas do tipo dibenzilbutirolactona, matairesinosídeo (1) e arctiina (2). As estruturas destas lignanas foram elucidadas através de análises espectroscópicas completas bem como por comparação direta dos dados experimentais com os respectivos dados da literatura.
\end{abstract}

Unitermos: Centaurea urvillei subs. armata, Centaurea mucronifera, Asteraceae, Compositae, lignana, arctiina, matairesinosídeo, DPPH, MTT, Artemia salina, toxicidade.

\begin{abstract}
The antioxidant activity, general toxicity and cytotoxicity of the methanol extracts of Centaurea urvillei subs. armata and C. mucronifera have been assessed, respectively, by the DPPH assay, the brine shrimp lethality and the MTT cytotoxicity assays. The reversed-phase HPLC analysis of the methanol extracts afforded two bioactive dibenzylbutyrolactone-type lignans, matairesinoside (1) and arctiin (2). The structures of these lignans were elucidated by comprehensive spectroscopic analyses as well as by the direct comparison of experimental data with respective literature data.
\end{abstract}

Keywords: Centaurea urvillei subs. armata, Centaurea mucronifera, Asteraceae, Compositae, lignan, arctiin, matairesinoside, DPPH, MTT, brine shrimp lethality assay.

\section{INTRODUCTION}

Centaurea urvillei subs. armata Wagenitz and $C$. mucronifera DC. (Family: Asteraceae alt. Compositae), are two Turkish endemic perennials that are distributed in the Mediterranean, the Middle and the Eastern Anatolian regions of Turkey (Wagenitz, 1975). To our knowledge, no reports on the isolation of any plant secondary metabolites or any pharmacological properties of these plants are available to date. However, many species of the genus Centaurea have long been used in traditional medicine to cure various ailments, e.g. diabetes, diarrhoea, rheumatism, malaria, hypertension, treatment of drug dependence etc., and a variety of secondary metabolites have been reported from different species of this genus
(Sarker et al., 1997; Carlini et al., 2006). As a part of our continuing phytochemical and bioactivity studies on the species of the genus Centaurea (Shoeb et al., 2006a,b; 2005; 2004a,b; Sarker et al., 2005; 2001; 1998; 1997), we now report on the assessment of the extracts of $C$. urvillei subs. armata and C. mucronifera for antioxidant activity, general toxicity and cytotoxicity, respectively, by the DPPH assay, the brine shrimp lethality and the MTT cytotoxicity assays, and the isolation and identification of two major bioactive lignans, matairesinoside (1) and arctiin (2), from these plants.

\section{MATERIAL AND METHODS}

\section{General}

ISSN 0102-695X 
UV spectra were obtained in $\mathrm{MeOH}$ using a Hewlett-Packard 8453 UV-vis spectrometer. MS analyses were performed on a Quattro II triple quadrupole instrument. NMR spectra were recorded in $\mathrm{CD}_{3} \mathrm{OD}$ on a Varian Unity INOVA $400 \mathrm{MHz}$ NMR Spectrometer 400 (400 MHz for ${ }^{1} \mathrm{H}$ and $100 \mathrm{MHz}$ for ${ }^{13} \mathrm{C}$ ) using the residual solvent peaks as internal standard. HPLC separation was performed using a Dionex prep-HPLC system coupled with Gynkotek GINA50 autosampler and Dionex UVD340S Photo-Diode-Array detector and/or A JASCO PU-1580 Intelligent HPLC Pump, coupled with JASCO DG-1580-53 Degasser and JASCO LG-1580-02 Ternary Gradient Unit. A Luna $\mathrm{C}_{18}$ preparative $(10 \mu \mathrm{M}, 250 \mathrm{~mm}$ $\times 21.2 \mathrm{~mm}$ ) and/or a Luna $\mathrm{C}_{18}$ semi-preparative HPLC column (5 $\mu \mathrm{M}, 250 \mathrm{~mm}$ x $10 \mathrm{~mm})$ were used. Sep-Pak Vac 35 cc (10 g) $\mathrm{C}_{18}$ cartridge (Waters) was used for preHPLC fractions. HMBC spectra were optimised for a long range $J_{\mathrm{H}-\mathrm{C}}$ of $9 \mathrm{~Hz}$ and the NOESY experiment was carried out with a mixing time of 0.8 s.

\section{Plant material}

The aerial parts of Centaurea urvillei subs. armata and C. mucronifera were collected from Anatolia, Turkey. Voucher specimens PHSH80012 and PHSH0013, respectively, for C. urvillei subs. armata and C. mucronifera have been retained in the herbarium of the Plant and Soil Science Department, University of Aberdeen, Scotland (ABD).

\section{Extraction, isolation and structure elucidation}

Dried ground aerial parts of $C$. urvillei subs. armata and C. mucronifera (100 g) were separately, Soxhlet-extracted, successively, with $n$-hexane, dichloromethane and methanol (MeOH) (1 L each). The $\mathrm{MeOH}$ extract $(2.0 \mathrm{~g})$ of $C$. urvillei was fractionated by solid-phase extraction method using a Sep-Pak $\mathrm{C}_{18}(10$ g) cartridge eluting with a step gradient: $40,60,80$ and $100 \% \mathrm{MeOH}$ in water (200 mL each). Prep-HPLC (eluted with a linear gradient- water:MeOH $=75: 25$ to $30: 70$ over $50 \mathrm{~min}$ followed by $70 \% \mathrm{MeOH}$ for $10 \mathrm{~min}, 20 \mathrm{~mL} /$ min) of the Sep-Pak fraction, which was eluted with $40 \%$ $\mathrm{MeOH}$, yielded compounds 1 (12.4 mg, $t_{\mathrm{R}}=20.6 \mathrm{~min}$ ) and 2 (56.0 $\left.\mathrm{mg}, t_{\mathrm{R}}=24.5 \mathrm{~min}\right)$. The 'dereplication' of the Sep-Pak fractions of the $\mathrm{MeOH}$ extract $(100 \mathrm{mg})$ of $C$. mucronifera using the HPLC-PDA analyses revealed the presence of exactly the same lignans ( $\mathbf{1}$ and $\mathbf{2}$ ) in the SepPak fraction, which was eluted with $40 \% \mathrm{MeOH}$.

Matairesinoside (1): Gum, $[\alpha]_{\mathrm{D}}^{23}-48.8^{\circ}$ (c 0.002 , $\mathrm{MeOH}) ; \mathrm{UV} \lambda_{\max }(\mathrm{MeOH}): 279,222 ;$ IR $v_{\text {max }}$ (neat): 3373, 1760, 1600, 1514, 1452 and $1270 \mathrm{~cm}^{-1}$; ESIMS $\mathrm{m} / \mathrm{z} 543$ $[\mathrm{M}+\mathrm{Na}]^{+} ;{ }^{1} \mathrm{H}\left(400 \mathrm{MHz}, \mathrm{CD}_{3} \mathrm{OD}\right)$ and ${ }^{13} \mathrm{C}$ NMR (100 $\mathrm{MHz}, \mathrm{CD}_{3} \mathrm{OD}$ ): as published data (Shoeb et al., 2004a).

Arctiin (2): Gum, [ $\alpha{ }^{23}-55.3^{\circ}$ (с 0.0033, $\mathrm{MeOH}) ; \mathrm{UV} \lambda_{\text {max }}(\mathrm{MeOH}): 279,225 ; \mathrm{IR} v_{\text {max }}$ (neat): 3459, 1765, 1591, 1460 and $1266 \mathrm{~cm}^{-1}$; CIMS m/z $552[\mathrm{M}+$
$\left.\mathrm{NH}_{4}\right]^{+} ;{ }^{1} \mathrm{H}\left(400 \mathrm{MHz}, \mathrm{CD}_{3} \mathrm{OD}\right)$ and ${ }^{13} \mathrm{C}$ NMR $(100 \mathrm{MHz}$, $\mathrm{CD}_{3} \mathrm{OD}$ ): as published data (Shoeb et al., 2004a).

\section{DPPH assay}

2,2-Diphenyl-1-picrylhydrazyl (DPPH), molecular formula $\mathrm{C}_{18} \mathrm{H}_{12} \mathrm{~N}_{5} \mathrm{O}_{6}$, was obtained from Fluka Chemie AG, Bucks. Quercetin was obtained from Avocado Research Chemicals Ltd, Shore road, Heysham, Lancs. The method used by Takao et al. (1994) was adopted with suitable modifications (Kumarasamy et al. 2002). DPPH (4 mg) was dissolved in $\mathrm{MeOH}(50 \mathrm{~mL}$ ) to obtain a concentration of $80 \mu \mathrm{g} / \mathrm{mL}$.

Qualitative assay: Test samples (MeOH extract, 1 and 2) were applied on a TLC plate and sprayed with DPPH solution using an atomiser. It was allowed to develop for $30 \mathrm{~min}$. The colour changes (purple on white) were noted.

Quantitative assay: The $\mathrm{MeOH}$ extract, and test compounds 1 and 2 were dissolved in $\mathrm{MeOH}$ to obtain a concentration of $1.0 \mathrm{mg} / \mathrm{mL}$. Dilutions were made to obtain concentrations of $5 \times 10^{-1}, 5 \times 10^{-2}, 5 \times 10^{-3}, 5 \times 10^{-}$ ${ }^{4}, 5 \times 10^{-5}, 5 \times 10^{-6} 5 \times 10^{-7}, 5 \times 10^{-8}, 5 \times 10^{-9}, 5 \times 10^{-10} \mathrm{mg} /$ $\mathrm{mL}$. Diluted solutions (1.00 mL each) were mixed with DPPH $(1.00 \mathrm{~mL})$ and allowed to stand for $30 \mathrm{~min}$ for any reaction to occur. The UV absorbance was recorded at 517 $\mathrm{nm}$. The experiment was performed in triplicate and the average absorption was noted for each concentration. The same procedure was followed for the positive standards (quercetin).

\section{Brine shrimp lethality assay}

Shrimp eggs were purchased from The Pet Shop, Kittybrewster Shopping Complex, Aberdeen, UK. The bioassay was conducted following the procedure described by Meyer et al. (1982). The eggs were hatched in a conical flask containing $300 \mathrm{~mL}$ artificial seawater. The flasks were well aerated with the aid of an air pump, and kept in a water bath at $29-30{ }^{\circ} \mathrm{C}$. A bright light source was left on and the nauplii hatched within $48 \mathrm{~h}$. The methanol extracts of two species and the test compounds (1 and 2) were dissolved in 20\% aq. DMSO to obtain a concentration of $1 \mathrm{mg} / \mathrm{mL}$. These were serially diluted two-times, and seven different concentrations were obtained. A solution of each concentration $(1 \mathrm{~mL})$ was transferred into clean sterile universal vials with pipette, and aerated sea-water $(9 \mathrm{~mL})$ was added. About 10 nauplii were transferred into each vial with pipette. A check count was performed and the number alive after $24 \mathrm{~h}$ was noted. $\mathrm{LD}_{50} \mathrm{~s}$ were determined using the Probit analysis method (Finney, 1971).

\section{MTT cytotoxicity assay}

CaCo-2 cells were maintained in Earle's minimum essential medium (Sigma), supplemented 
with $10 \%(\mathrm{v} / \mathrm{v})$ foetal calf serum (Labtech Int.), $2 \mathrm{mM}$ L-glutamine (Sigma), 1\% (v/v) non-essential amino acids (Sigma), $100 \mathrm{IU} / \mathrm{mL}$ penicillin and $100 \mu \mathrm{g} / \mathrm{mL}$ streptomycine (Sigma). Exponentially growing cells were plated at $2 \times 10^{4}$ cells $\mathrm{cm}^{-2}$ into 96-well plates and incubated for $72 \mathrm{~h}$ before the addition of drugs. Stock solution of compounds was initially in DMSO or $\mathrm{H}_{2} \mathrm{O}$ and further diluted with fresh complete medium.

The growth-inhibitory effects of the methanol extracts of two Centaurea species and the test compounds (1-2) were assessed using the standard tetrazolium MTT assay (Mosmann, 1983). After $72 \mathrm{~h}$ of incubation at $37^{\circ} \mathrm{C}$, the medium was removed, and $100 \mu \mathrm{L}$ of MTT reagent $(1 \mathrm{mg} / \mathrm{mL})$ in serum free medium was added to each well. The plates were incubated at $37^{\circ} \mathrm{C}$ for $4 \mathrm{~h}$. At the end of the incubation period, the medium was removed and pure DMSO $(200 \mu \mathrm{L})$ was added to each well. The metabolised MTT product dissolved in DMSO was quantified by reading the absorbance at $560 \mathrm{~nm}$ on a micro plate reader (Dynex Technologies, USA). The $\mathrm{IC}_{50}$ values were calculated from the equation of the logarithmic line determined by fitting the best line (Microsoft Excel) to the curve formed from the data. The $\mathrm{IC}_{50}$ value was obtained from the equation $\mathrm{y}=50$ (50\% value).

\section{RESULTS AND DISCUSSION}

The $\mathrm{MeOH}$ extracts of $C$. urvillei subs. armata and C. mucronifera were tested for antioxidant activity, general toxicity and cytotoxicity, respectively, by the DPPH assay, the brine shrimp lethality and the MTT cytotoxicity assays. The crude $\mathrm{MeOH}$ extracts of C. urvillei subs. armata and C. mucronifera showed significant levels of free radical scavenging activity (antioxidant activity) $\left(\mathrm{IC}_{50}=51.6 \times 10^{-2}\right.$ and $53.6 \times 10^{-}$ ${ }^{2} \mathrm{mg} / \mathrm{mL}$ ) in the DPPH assay (Table 1) which was due to the presence of two lignans, matairesinoside (1) and arctiin (2) with significant antioxidant properties $\left(\mathrm{IC}_{50}=\right.$ $2.2 \times 10^{-3}$ and $16.0 \times 10^{-2}$ and $\mathrm{mg} / \mathrm{mL}$, respectively).

The brine shrimp lethality assay has been demonstrated to be an effective, robust and rapid assay method for primary screening of compounds for potential cytotoxic activities (Meyer et al., 1982). The $\mathrm{MeOH}$ extracts of C. urvillei subs. armata and C. mucronifera were found to possess similar levels of general toxicities with the $\mathrm{LD}_{50}$ values of $115.5 \times 10^{-2}$ and $120.0 \times 10^{-2} \mathrm{mg} /$ $\mathrm{mL}$, respectively (Table 1). Again, the lignans 1 and 2, as the major components present in the extracts, contributed to this activity $\left(\mathrm{LD}_{50}\right.$ values of $1.6 \times 10^{-2}$ and $9.8 \times 10^{-2}$ $\mathrm{mg} / \mathrm{mL}$, respectively).

While none of the extracts demonstrated any significant cytotoxicity against the CaCo-2 colon cancer cell line in the MTT assay $\left(\mathrm{IC}_{50}=>1000 \mu \mathrm{g} /\right.$ $\mathrm{mL}$ ), the isolated lignans ( $\mathbf{1}$ and $\mathbf{2})$ showed considerable cytotoxicity (Table 1 ). The $\mathrm{IC}_{50}$ values for matairesinoside (1) and arctiin (2) were 220 and $288 \mu \mathrm{M}$. It has previously been observed that it is not at all surprising to have active<smiles>[R][R]Nc1ccc(C[C@H]2COC(=O)[C@@H]2Cc2ccc(O[C@@H]3O[C@H](CO)[C@@H](O)[C@H](O)[C@H]3O)c(OC)c2)cc1OC</smiles>

Table 1. Antioxidant (DPPH assay) and brine shrimp toxicity (Brine Shrimp Lethality assay), and cytotoxic (MTT assay) activities, of the $\mathrm{MeOH}$ extracts of Centaurea urville subs. armata and C. mucronifera, and the lignans (1 and 2).

\begin{tabular}{|c|c|c|c|}
\hline $\mathrm{MeOH}$ extracts/ Compounds & $\begin{array}{c}\text { Antioxidant } \\
\text { activity } \\
\mathrm{IC}_{50}(\mathrm{mg} / \mathrm{mL})\end{array}$ & $\begin{array}{l}\text { Brine shrimp toxicity } \\
\operatorname{LD}_{50}(\mathrm{mg} / \mathrm{mL})\end{array}$ & $\begin{array}{c}\text { Cytotoxicity } \\
\mathrm{IC}_{50}(\mu \mathrm{M})^{\mathrm{a}}, \mu \mathrm{g} / \mathrm{mL}^{\mathrm{b}}\end{array}$ \\
\hline C. urvillei & $51.6 \times 10^{-2}$ & $115.5 \times 10^{-2}$ & $>100^{b}$ \\
\hline C. mucronifera & $53.6 \times 10^{-2}$ & $120.0 \times 10^{-2}$ & $>100^{\mathrm{b}}$ \\
\hline Matairesinoside (1) & $2.2 \times 10^{-2}$ & $1.6 \times 10^{-2}$ & $220.0^{\mathrm{a}}$ \\
\hline $\operatorname{Arctiin}(2)$ & $16.0 \times 10^{-3}$ & $9.8 \times 10^{-2}$ & $288.0^{\mathrm{a}}$ \\
\hline Quercetin (positive control) & $2.88 \times 10^{-5}$ & - & - \\
\hline \multirow[t]{2}{*}{ Podophyllotoxin (positive control) } & - & $2.79 \times 10^{-3}$ & 0.06 \\
\hline & & & $\begin{array}{r}\text { Rev. Bras. Farmacogn. } \\
\text { Braz J. Pharmacogn. } \\
\text { 17(2): Abr./Jun. } 2007\end{array}$ \\
\hline
\end{tabular}


compounds from inactive extracts or fractions as the amounts of active compounds present in the amounts of extracts or fractions tested can be too small to show any activity (Shoeb et al., 2006a).

Reversed phase HPLC analyses of the $40 \%$ SepPak fraction of the methanol extracts of $C$. urvillei subs. armata and C. mucronifera afforded two known bioactive dibenzylbutyrolactone-type lignans, matairesinoside (1) and arctiin (2). The structures of these compounds were elucidated by comprehensive spectroscopic analyses, and also by direct comparison with the respective published data (Shoeb et al., 2004a). Compounds 1 and 2 displayed characteristic UV absorption maxima of dibenzylbutyrolactone-type lignans (Shoeb et al., 2004a). The ${ }^{1} \mathrm{H}$ and ${ }^{13} \mathrm{C}$ NMR spectra of these compounds also supported this fact. A CIMS spectrum of 2 revealed the $\left[\mathrm{M}+\mathrm{NH}_{4}\right]^{+}$ion peak at $\mathrm{m} / \mathrm{z} 552$, suggesting $\mathrm{Mr}=534$, and the molecular formula $\mathrm{C}_{27} \mathrm{H}_{34} \mathrm{O}_{11}$. The ${ }^{1} \mathrm{H}$ and ${ }^{13} \mathrm{C}$ NMR spectral data of $\mathbf{2}$ were identical to those published for arctiin (2) (Shoeb et al., 2004a). A combination of HMQC, HMBC, COSY and NOESY 2D NMR spectral analyses led to the unambiguous assignment of all ${ }^{1} \mathrm{H}$ and ${ }^{13} \mathrm{C}$ NMR signals of 2 and confirmed unequivocally its identity as arctiin (2).

The ${ }^{1} \mathrm{H}$ and ${ }^{13} \mathrm{C}$ NMR data of $\mathbf{1}$ were similar to those of arctiin (2) with the exception that one methoxyl signal was missing. The CIMS spectrum of 1 revealed $\left[\mathrm{M}+\mathrm{NH}_{4}\right]^{+}$ion at $m / z 538$, suggesting $\mathrm{Mr}=520$, and the molecular formula $\mathrm{C}_{26} \mathrm{H}_{32} \mathrm{O}_{11}$ which also confirmed the findings from the NMR data that it contained 14 mass units less than arctiin (2), i.e. instead of a methoxyl group, it had a hydroxyl group present. The ${ }^{1} \mathrm{H}$ and ${ }^{13} \mathrm{C}$ NMR data of $\mathbf{1}$ were in good agreement with the published data of matairesinoside (Shoeb et al., 2004a). Using the HPLCPDA-based 'dereplication' protocol, the lignans 1 and $\mathbf{2}$ were also unambiguously identified in the $40 \%$ Sep-Pak fraction of the $\mathrm{MeOH}$ extract of $C$. mucronifera, and so was not processed for further purification.

These lignans were previously reported from a few other species of the genus Centaurea (ISI database, 2006; Shoeb et al., 2004a). However, this is the first report on the occurrence of matairesinoside (1) and arctiin (2) in C. urvillei subs. armata and C. mucronifera. The co-occurrence of these dibenzylbutyrolactone lignans (1 and 2) within the genus Centaurea might be chemotaxonomically significant.

The overall bioactivity profiles of the $\mathrm{MeOH}$ extracts of $C$. urvillei subs. armata and C. mucronifera were almost identical (Table 1). It is interesting, but not unexpected, to note that both extracts have the same chemical profiles as well, and contain matairesinoside (1) and arctiin (2) as the major bioactive compounds.

\section{ACKNOWLEDGEMENTS}

We thank the EPSRC National Mass Spectrometry Service Centre (Department of Chemistry,
University of Wales Swansea, Swansea, Wales, UK) for CIMS analyses.

\section{REFERENCES}

Carlini EA, Rodrigues E, Mendes FR, Tabach R, Gianfratti B 2006. Treatment of drug dependence with Brazilian herbal medicines. Rev Bras Farmacogn 16: 690-695.

Finney D 1971. Probit analysis, $3^{\text {rd }}$ eD., Cambridge University Press, Cambridge.

ISI Database 2006. Institute for Scientific Information, UK. Available on-line through Web of Science at: http:// wos.mimas.ac.uk.

Kumarasamy Y, Fergusson M, Nahar L, Sarker SD 2002. Biological activity of moschamindole from Centaurea moschata. Pharm Biol 40: 307-310.

Meyer BN, Ferrigni RN, Putnam JE, Jacobsen LB, Nichols DE, Mclaughlin JL 1982. Brine shrimp - A convenient general bioassay for active plants constituents. Planta Med 45: 31-34

Mosmann T 1983. Rapid colorimetric assay for the cellular growth and survival: application to proliferation and cytotoxicity assays. J Immunol Methods 65: 55-63.

Sarker SD, Kumarasamy Y, Shoeb M, Celik S, Yucel E, Middleton M, Nahar L 2005. Antibacterial and antioxidant activities of three Turkish species of the gemus Centaurea. Oriental Pharmacy and Experimental Medicine 5: 246-250.

Sarker SD, Laird A, Nahar L, Kumarsamy Y, Jaspars M 2001. Indole alkaloids from the seeds of Centaurea cyanus (Asteraceae). Phytochemistry 57: 1273-1276.

Sarker SD, Dinan L, Sik V, Underwood E, Waterman PG 1998. Moschamide: an unusual alkaloid from the seeds of Centaurea moschata. Tetrahedron Lett 39: 14211424.

Sarker SD, Savchenko T, Whiting P, Sik V, Dinan LN 1997. Moschamine, cis-moschamine, moschamine, moschamindole and moschamindolol: four novel indole alkaloids from Centaurea moschata. Nat Prod Lett 9: 189-199.

Shoeb M, MacManus SM, Kumarasamy Y, Jaspars M, Nahar L, Kong-Thoo-Lin P, Nazemiyeh H, Sarker SD 2006a. Americanin, a bioactive dibenzylbutyrolactone lignan, from the seeds of Centaurea americana. Phytochemistry 67: 2370-2375.

Shoeb M, MacManus SM, Jaspars M, Trevidu J, Nahar L, Kong-Thoo-Lin P, Sarker SD 2006b. Montamine, a unique dimeric indole alkaloid, from the seeds of Centaurea montana (Asteraceae), and its in vitro cytotoxic activity against the $\mathrm{CaCo}-2$ colon cancer cells. Tetrahedron 62: 11172-11177.

Shoeb M, Celik S, Jaspars M, Kumarasamy Y, MacManus SM, Nahar L, Kong-Thoo-Lin P, Sarker SD 2005. Isolation, structure elucidation and bioactivity of schischkiniin, a unique indole alkaloid from the seeds of Centaurea schischkini Tetrahedron 61: 9001-9006.

Shoeb M, Rahman MM, Nahar L, Jaspars M, MacManus S, Delazar A, Sarker SD 2004a. Bioactive lignans from the seeds of Centaurea macrocephala. DARU Journal of Tehran School of Pharmacy 12: 87-93.

Shoeb M, Jaspars M, MacManus SM, Majinda RRT, Sarker SD 2004b. Epoxylignans from the seeds of Centaurea cyanus. Biochem Syst Ecol 32: 1201-1204. 
Takao T, Watanabe N, Yagi I, Sakata K 1994. A simple screening method for antioxidants and isolation of several antioxidants produced by marine bacteria from fish and shellfish. Biosci Biotech Biochem 58: 1780-1783.

Wagentiz G 1975. Flora of Turkey and the East Aegean Islands, Davis, P.H, Eds., University Press, Edinburgh, 5. 